\title{
THE NEED FOR INTERNATIONAL POLICY COORDINATION: WHAT'S OLD, WHAT'S NEW, WHAT'S YET TO COME?
}

\author{
Matthew B. Canzoneri \\ Robert E. Cumby \\ Behzad T. Diba \\ Working Paper 8765 \\ http://www.nber.org/papers/w8765 \\ NATIONAL BUREAU OF ECONOMIC RESEARCH \\ 1050 Massachusetts Avenue \\ Cambridge, MA 02138 \\ February 2002
}

We would like to thank (without implicating) Dale Henderson for useful discussions and suggestions. The views expressed herein are those of the authors and not necessarily those of the National Bureau of Economic Research.

(C) 2002 by Matthew B. Canzoneri, Robert E. Cumby and Behzad T. Diba. All rights reserved. Short sections of text, not to exceed two paragraphs, may be quoted without explicit permission provided that full credit, including (C) notice, is given to the source. 
The Need for International Policy Coordination:

What's Old, What's New, What's Yet to Come?

Matthew B. Canzoneri, Robert E. Cumby and Behzad T. Diba

NBER Working Paper No. 8765

February 2002

JEL No. E42, E52, F41, F42

\begin{abstract}
Fifty years ago, the Chicago School argued that flexible exchange rates would insulate employment from foreign economic disturbances: there is no need for policy coordination; flexible exchange rates suffice. Twenty five years later, the Bretton Woods system was gone, and the first generation of policy coordination models was introduced. Chicago School arguments not withstanding, these Old-Keynesian models provided a theoretical rational for policy coordination. Now, a new generation of policy coordination models is emerging. These New-Keynesian models incorporate optimizing households, monopolistic competition and nominal inertia. Here, we examine macroeconomic interdependence and the scope for policy coordination in a tractable second generation model that has received much recent attention. We relate our discussion to the old Chicago School arguments, to earlier analyses of first generation models, to recent empirical work on productivity, and to recent theoretical work on closed economy models. We conclude that second generation models may have more scope for policy coordination than did the first, and we identify the empirical work that is needed to give a serious answer to the question.
\end{abstract}

\author{
Matthew B. Canzoneri \\ Economics Department \\ Georgetown University \\ canzonem@georgetown.edu
}

\author{
Robert E. Cumby \\ Behzad T. Diba \\ Economics Department \\ Georgetown University \\ Economics Department \\ Georgetown University \\ dibab@georgetown.edu
}




\section{Introduction}

Fifty years ago, during the Bretton Woods era, the Chicago School asserted that a flexible exchange rate would insulate domestic employment from foreign economic disturbances, including foreign monetary policy. ${ }^{1}$ There is no need, they argued, for central banks to intervene in foreign exchange markets or coordinate their monetary policies; all that is needed is flexible exchange rates. Twenty five years later, the Bretton Woods system of fixed exchange rates was gone, and Hamada (1974, 1979), Oudiz and Sachs (1984) and Canzoneri and Gray (1985) introduced the first generation of game-theoretic models to describe monetary policy coordination. ${ }^{2}$ These Old-Keynesian models - the assertions of the Chicago School not withstanding - did provide a theoretical rational for policy coordination, but found that the gains from coordination were quantitatively small. Now, Obstfeld and Rogoff (2000b)(O\&Rb) and Corsetti and Pesenti (2001b) (C\&Pb) have introduced a new generation of policy coordination models. These New-Keynesian models incorporate optimizing households, monopolistic competition, and some form of nominal inertia. ${ }^{3}$ The need for policy coordination in second generation models is still an open question, but O\&Rb's initial results made them rather skeptical. They asked: "Do we really need a new international monetary compact?", and they concluded: "Surprisingly, the answer may be no".

In this paper, we examine macroeconomic interdependence and the need for policy coordination in a prototypical second generation model. We relate our findings to the old arguments of the Chicago School, to earlier analyses of first generation models, to recent empirical work on productivity differences across sectors (as implied by the Balassa-Samuelson hypothesis), and to recent theoretical developments in the closed economy literature. We conclude that second generation models may have more scope for policy coordination than did the first.

Obstfeld and Rogoff (2000a)(O\&Ra) and Corsetti and Pesenti (2001a)(C\&Pa) developed a 
path breaking Workhorse Model for the study of macroeconomic interdependence. In accordance with the recent literature on monetary policy, the model includes optimizing households in each country, monopolistic competition, nominal inertia, and a stochastic environment. Three strategically chosen characteristics make the Workhorse Model amazingly tractable: (1) a balanced current account, (2) constant expenditure shares (on components of the composite consumption good), and (3) a log specification for the utility of money. ${ }^{4}$ The Workhorse Model readily admits exact solutions, even in this inherently complex framework.

Our discussion of the macroeconomic interdependence exhibited by this Workhorse Model will be reminiscent of the old Chicago School assertions: flexible exchange rates insulate domestic employment and output from all foreign disturbances, including foreign monetary policy. The three characteristics that account for the truly amazing tractability of the Workhorse Model carry with them a certain amount of collateral damage: the theory of exchange rate determination embodied in the Workhorse Model is extremely simple (the exchange rate just depends on the ratio of home and foreign money supplies), and as a result the macroeconomic interdependence is rather limited.

The insularity of employment in the Workhorse Model might have limited the scope for policy coordination in the first generation models, since Old-Keynesian models focused on stabilization of employment. However, first generation models also postulated an inflation goal for monetary policy, and Canzoneri and Henderson (1991) have shown that policy spillovers in inflation can imply a need for coordination, even when there is no interdependence in employment.

As $\mathrm{O} \& \mathrm{Rb}$ have emphasized, second generation models already have a natural measure of national welfare in the utility of the representative household, and this imposes a new discipline on policy coordination exercises: we can't just postulate a separate goal for inflation; it has to be welfare 
based. As we shall see, there is a stabilization goal for monetary policy embedded in the household utility functions, but there is no separate inflation goal. However, we shall also see that the Workhorse Model focuses on stabilization of consumption, rather than employment. And oddly enough, in the Workhorse Model, the foreign money supply is the only policy variable that affects domestic consumption of the imported good $;{ }^{5}$ so, policy coordination might play an important role in the Workhorse Model despite its lack of supply side interdependence.

However, both $\mathrm{O} \& \mathrm{Rb}$ and $\mathrm{C} \& \mathrm{~Pb}$ found that there is no need for coordination in the Workhorse Model. Both extended the Workhorse Model in ways that would provide a role for policy coordination. $\mathrm{C} \& \mathrm{~Pb}$ 's extension allowed exporter to partially index their prices to exchange rate movements, while $\mathrm{O} \& \mathrm{Rb}$ 's extension created a role for international risk sharing. $\mathrm{O} \& \mathrm{Rb}$ calibrated their model and found that the gains from coordination were second order when compared to the gains from simply reacting to shocks in a sensible way at the national level (as in a Nash solution). Their finding is reminiscent of the conclusions in McKibbin's (1997) survey of the first generation models; in fact, McKibbin reports that the same conclusion has attained the status of a folk theorem in the literature on first generation models.

We will not pursue either of these extensions here. Instead, we will return to the basic Workhorse Model and ask why it implies no need for policy coordination, despite the strong policy spillovers in consumption. The reason is straightforward: central banks are able to achieve the flexprice outcome in the Nash solution. Since the flex-price outcome is the (constrained) optimum in the Workhorse Model, Nash and Cooperative solutions coincide. There must be a policy tradeoff (or friction) in the Nash solution if there is going to be a role for policy coordination. If a tradeoff remains, then central banks may be able to help each other to get closer the flex-price outcome. 
We will discuss two new ways of introducing a policy tradeoff in the Nash solution of the Workhorse Model. One is suggested by recent empirical work on the Balassa-Samuelson hypothesis; the other is suggested by recent theoretical work on closed economy models. Both $\mathrm{O} \& \mathrm{Rb}$ and $\mathrm{C} \& \mathrm{~Pb}$ assume that productivity shocks are perfectly correlated across traded and nontraded good sectors. Empirical work on the Balassa-Samuelson hypothesis suggests that the stochastic processes generating productivity shocks in the two sectors are quite different. ${ }^{6}$ Relaxing the assumption that productivity shocks are perfectly correlated introduces a tradeoff in the Nash solution in the Workhorse Model. O\&Rb and $\mathrm{C} \& \mathrm{~Pb}$ also assume that the wage and price setting behavior is symmetric across sectors. In the closed economy literature, Erceg, Henderson and Levin (2000) have shown that asymmetries can create a policy tradeoff (even if productivity shocks are perfectly correlated).

In this paper, we will explain why asymmetries in wage and price setting lead to a policy tradeoffs, and we will model explicitly the case where productivity shocks vary across sectors. We will show that, depending on the size and correlation of various shocks, the gains from coordination can be second order, first order, or quite large in comparison with simply reacting to the shocks in a sensible way at a national level (as in a Nash solution). Canzoneri and Minford's (1988) analysis of the structure of first generation models suggested that the gains from coordination in those models must necessarily be small. Our examples illustrate that this is not the case with second generation models. In this sense, there is reason to think that second generation models may offer more scope for policy coordination than did the first.

Devereux and Engel $(2000,2001)$ have shown that it can be important to note which currency exporters use when they set their prices. Most of the discussion above assumes producer currency 
pricing, but we will also consider customer currency pricing. The Workhorse Model exhibits a very different kind of insularity in this case: consumption (and not employment) is insulated from foreign monetary policy. As $\mathrm{C} \& \mathrm{~Pb}$ have noted, this precludes any role for policy coordination.

The rest of the paper is organized as follows: In Section II, we outline our version of the Workhorse Model; the only essential difference with O\&Ra and C\&Pa is that we do not assume productivity shocks are perfectly correlated across sectors in each country. In Section III, we analyze the macroeconomic interdependence exhibited by the Workhorse Model. In Section IV, we assess the scope for policy coordination in the Workhorse Model. In section V, we conclude by identifying the empirical work that is needed for a more definitive answer to Obstfeld and Rogoff's question.

\section{The Workhorse Model}

The Workhorse Model is characterized by: (1) a balanced current account, (2) constant expenditure shares on the commodities that make up the composite consumption bundle in each country, and (3) log utility of money. A Cobb-Douglas consumption aggregator fixes the expenditure shares. Following O\&Ra, we simply impose current account balance by assuming that there is no capital mobility, but as C\&Pa have shown, the current account would be balanced in an intertemporal extension of our model. ${ }^{7}$ The only substantive way in which our version of the Workhorse Model differs from the models of O\&Ra and C\&Pa is that we allow productivity shocks to differ across sectors.

We begin by defining the sectors in the Workhorse Model. Following C\&Pa and O\&Rb, we will distinguish between tradable goods and non-tradable goods. However, we will also distinguish between tradable goods that are sold domestically and tradable goods that are sold abroad. This is 
motivated by the possibility that transportation technologies or distribution networks may differ in the domestic and export markets.

The production technology is linear and stochastic, and (as we shall soon see) the disutility of work is also linear. So, products are essentially defined by the labor it takes to produce them. One unit of labor produces $\mathrm{Z}_{\mathrm{N}}$ non-tradable goods, $\mathrm{Z}_{\mathrm{D}}$ tradable goods that are sold domestically, or $\mathrm{Z}_{\mathrm{E}}$ tradeable goods that are exported. Similarly, in the foreign country, one unit of labor produces $\mathrm{Z}_{\mathrm{N}^{*}}$ non-tradeable goods, $\mathrm{Z}_{\mathrm{D}^{*}}$ tradeable goods that are sold domestically, or $\mathrm{Z}_{\mathrm{E}^{*}}$ tradeable goods that are exported. Our general framework encompasses two interesting special cases. One lets productivity shocks be perfectly correlated across the tradeable goods sectors: $Z_{D}=Z_{E} \equiv Z_{T}$ and $Z_{D^{*}}$ $=\mathrm{Z}_{\mathrm{E}^{*}} \equiv \mathrm{Z}_{\mathrm{T}}^{*}$. The other lets productivity shocks be perfectly correlated across all sectors in each

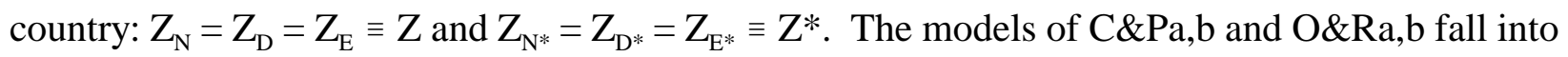
the last case.

The new generation of policy coordination models assumes utility maximizing households, monopolistic competition, and some form of nominal inertia. The simplest way of capturing these elements is to adopt a Yeoman-Farmer framework. In the home country, there is a continuum of households indexed by $\mathrm{h} \in[0,1]$. Each household has three workers: the first produces a traded good for the domestic market, $\mathrm{Y}_{\mathrm{D}}(\mathrm{h})$; the second produces a traded good for the export market, $\mathrm{Y}_{\mathrm{E}}(\mathrm{h})$; and the third produces a non-traded good, $\mathrm{Y}_{\mathrm{N}}(\mathrm{h})$. The utility of home household-h is given by:

(1) $\mathrm{U}(\mathrm{h})=\log (\mathrm{C}(\mathrm{h}))-\left[\left(\mathrm{Y}_{\mathrm{D}}(\mathrm{h}) / \mathrm{Z}_{\mathrm{D}}+\mathrm{Y}_{\mathrm{E}}(\mathrm{h}) / \mathrm{Z}_{\mathrm{E}}+\mathrm{Y}_{\mathrm{N}}(\mathrm{h}) / \mathrm{Z}_{\mathrm{N}}\right]+(1-v)^{-1}(\mathrm{M}(\mathrm{h}) / \mathrm{P})^{1-v}\right.$

where $C(h)=C_{D}(h)^{1 / 3} C_{E^{*}}(h)^{1 / 3} C_{N}(h)^{1 / 3}$ is a composite consumption good consisting of domestically produced traded goods, $\mathrm{C}_{\mathrm{D}}$, imported traded goods, $\mathrm{C}_{\mathrm{E}^{*}}$, and non-traded goods, $\mathrm{C}_{\mathrm{N}} ; \mathrm{Y}_{\mathrm{j}}(\mathrm{h}) / \mathrm{Z}_{\mathrm{j}}$ is the work effort of household-h in sector $\mathrm{j}$ (where $\mathrm{j}=\mathrm{D}, \mathrm{E}, \mathrm{N}$ ); and $\mathrm{M}(\mathrm{h}) / \mathrm{P}$ are money balances. The 
Workhorse Model assumes that $v=1$ (or more precisely, log utility of money), but we have entered real balances in a more general way so that we can show what happens when this assumption is relaxed. Foreign households are indexed by $\mathrm{h}^{*} \in[0,1]$; they are modeled in an analogous way.

The treatment of monopolistic competition in these models is now standard. ${ }^{8}$ Following Chari, Kehoe and McGrattan (1996), we assume the artifice of a bundler who assembles the output of households into the three commodities that make up the composite consumption good:

(2) $Y_{j}=\left[\int_{0}^{1} Y_{j}(h)^{(\theta-1) / \theta} d h\right]^{\theta /(\theta-1)} j=D, E, N$ and $Y_{j}=\left[\int_{0}^{1} Y_{j}\left(h^{*}\right)^{(\theta-1) / \theta} d^{*}\right]^{\theta /(\theta-1)} j=D^{*}, E^{*}, N^{*}$ (where $\theta>1$ ) and sells them for the commodity prices:

(3) $P_{j}=\left[\int_{0}^{1} P_{j}(h)^{(1-\theta)} d h\right]^{1 /(1-\theta)} \quad j=D, E, N$ and $P_{j}^{*}=\left[\int_{0}^{1} P_{j}\left(h^{*}\right)^{(1-\theta)} d h^{*}\right]^{1 /(1-\theta} \quad j=D^{*}, E^{*}, N^{*}$. The bundler's demand for the products of household-h and household-h* is:

(4) $Y_{j}(h)=\left(P_{j}(h) / P_{j}\right)^{-\theta} Y_{j} \quad j=D, E, N$ and $Y_{j}\left(h^{*}\right)=\left(P_{j}\left(h^{*}\right) / P_{j}\right)^{-\theta} Y_{j} \quad j=D^{*}, E^{*}, N^{*}$.

Another bundler assembles the commodities, $\mathrm{Y}_{\mathrm{j}}$, into the composite consumption goods:

(5) $\mathrm{C}=\mathrm{C}_{\mathrm{D}}{ }^{1 / 3} \mathrm{C}_{\mathrm{E}^{*}}{ }^{1 / 3} \mathrm{C}_{\mathrm{N}}{ }^{1 / 3}$ and $\mathrm{C}^{*}=\mathrm{C}_{\mathrm{D}^{*}}{ }^{1 / 3} \mathrm{C}_{\mathrm{E}}{ }^{1 / 3} \mathrm{C}_{\mathrm{N}^{*}}{ }^{1 / 3}$

and sells them to the home and foreign households at the prices:

(6) $\mathrm{P}=3 \mathrm{P}_{\mathrm{D}}^{1 / 3} \mathrm{P}_{\mathrm{E}^{*}}^{1 / 3} \mathrm{P}_{\mathrm{N}}^{1 / 3}$ and $\mathrm{P}^{*}=3 \mathrm{P}_{\mathrm{D}^{*}}^{* 1 / 3} \mathrm{P}_{\mathrm{E}}^{* 1 / 3} \mathrm{P}_{\mathrm{N}^{*}}^{* 1 / 3}$.

These are national consumer price indices. ${ }^{9}$ The bundler's cost minimization implies that:

(7) $\mathrm{P}_{\mathrm{D}} \mathrm{C}_{\mathrm{D}}=\mathrm{P}_{\mathrm{E}^{*}} \mathrm{C}_{\mathrm{E}^{*}}=\mathrm{P}_{\mathrm{N}} \mathrm{C}_{\mathrm{N}}=1 / 3 \mathrm{PC}$ and $\mathrm{P}_{\mathrm{D}^{*}}^{*} \mathrm{C}_{\mathrm{D}^{*}}=\mathrm{P}_{\mathrm{E}}^{*} \mathrm{C}_{\mathrm{E}}=\mathrm{P}_{\mathrm{N}^{*}}^{*} \mathrm{C}_{\mathrm{N}^{*}}=1 / 3 \mathrm{P}^{*} \mathrm{C}^{*}$.

One third of household expenditure is spent on each commodity in the composite consumption bundle; this gives us the "constant expenditure shares" characteristic of the Workhorse Model.

The budget constraint for household-h is given by:

(8) $\mathrm{M}(\mathrm{h})+\mathrm{PC}(\mathrm{h})+\mathrm{T}=\mathrm{M}_{0}(\mathrm{~h})+\mathrm{P}_{\mathrm{D}}(\mathrm{h})\left(\mathrm{P}_{\mathrm{D}}(\mathrm{h}) / \mathrm{P}_{\mathrm{D}}\right)^{-\theta} \mathrm{Y}_{\mathrm{D}}+\mathrm{P}_{\mathrm{E}}(\mathrm{h})\left(\mathrm{P}_{\mathrm{E}}(\mathrm{h}) / \mathrm{P}_{\mathrm{E}}\right)^{-\theta} \mathrm{Y}_{\mathrm{E}}+\mathrm{P}_{\mathrm{N}}(\mathrm{h})\left(\mathrm{P}_{\mathrm{N}}(\mathrm{h}) / \mathrm{P}_{\mathrm{N}}\right)^{-\theta} \mathrm{Y}_{\mathrm{N}}$ where $T$ is a tax, and $M_{0}(h)$ are initial money holdings. The household chooses $C(h), M(h), P_{N}(h)$, 
$\mathrm{P}_{\mathrm{D}}(\mathrm{h})$ and $\mathrm{P}_{\mathrm{E}}(\mathrm{h})$ (or $\mathrm{P}_{\mathrm{E}}^{*}(\mathrm{~h})$, as discussed below) to maximize (1) subject to (8). Some first order conditions hold for any assumption about the household's pricing policy:

(9) $1 / \lambda(h)=P C(h)$

(10) $(\mathrm{M}(\mathrm{h}) / \mathrm{P})^{-v}=1 / \mathrm{C}(\mathrm{h})$

where $\lambda(h)$ is the household's marginal utility of nominal wealth.

There are three different pricing policies that household-h might adopt. When prices are "flexible", the household sets its prices knowing the values of the productivity shocks. When prices are "fixed", the household sets its prices before the shocks are known; here, there are two different policies to consider. Under "producer currency pricing" (or PCP), the household sets its prices in terms of the currency it uses: a home household sets $P_{j}(h), j=D, E, N$. Under "customer currency pricing" (CCP), the household sets its prices in terms of the currency its customers use: a home household sets $\mathrm{P}_{N}(\mathrm{~h}), \mathrm{P}_{\mathrm{D}}(\mathrm{h})$ and $\mathrm{P}_{\mathrm{E}}^{*}(\mathrm{~h})=\mathrm{P}_{\mathrm{E}}(\mathrm{h}) / \mathrm{S}$, where $\mathrm{S}$ is the nominal exchange rate. ${ }^{10}$ With complete information (the flexible price case), it does not matter which currency the household uses to price its output; with incomplete information (the fixed price case), it may. Ideally, we would follow Devereux and Engel (2001) in endogenizing the household's choice of pricing policy, since the game situations we consider in Section IV might elicit a change. However, that task is too ambitious for us here.

When prices are flexible, household-h's first order conditions for price setting are:

$(11)_{\text {flex }} \mu \mathrm{P}_{\mathrm{j}}(\mathrm{h})^{-1-\theta}\left(1 / \mathrm{P}_{\mathrm{j}}\right)^{-\theta}\left(\mathrm{Y}_{\mathrm{j}} / \mathrm{Z}_{\mathrm{j}}\right)=\lambda(\mathrm{h}) \mathrm{P}_{\mathrm{j}}(\mathrm{h})^{-\theta}\left(1 / \mathrm{P}_{\mathrm{j}}\right)^{-\theta} \mathrm{Y}_{\mathrm{j}} \quad \mathrm{j}=\mathrm{D}, \mathrm{E}, \mathrm{N}$

where $\mu \equiv \theta /(\theta-1)$ is the "mark up" factor associated with monopolistic competition. When prices are fixed, the first order conditions are:

$$
\begin{aligned}
(11)_{\text {fixed }} \mu E\left[\mathrm{P}_{\mathrm{j}}(\mathrm{h})^{-1-\theta}\left(1 / \mathrm{P}_{\mathrm{j}}\right)^{-\theta}\left(\mathrm{Y}_{\mathrm{j}} / \mathrm{Z}_{\mathrm{j}}\right)\right]=\mathrm{E}\left[\lambda(\mathrm{h}) \mathrm{P}_{\mathrm{j}}(\mathrm{h})^{-\theta}\left(1 / \mathrm{P}_{\mathrm{j}}\right)^{-\theta} \mathrm{Y}_{\mathrm{j}}\right] & \mathrm{j}=\mathrm{D}, \mathrm{E}, \mathrm{N} \text { (for PCP) } \\
\mu E\left[\mathrm{P}_{\mathrm{j}}^{*}(\mathrm{~h})^{-1-\theta}\left(1 / \mathrm{P}_{\mathrm{j}}^{*}\right)^{-\theta}\left(\mathrm{Y}_{\mathrm{j}} / \mathrm{Z}_{\mathrm{j}}\right)\right]=\mathrm{E}\left[\lambda(\mathrm{h}) \mathrm{SP}_{\mathrm{j}}^{*}(\mathrm{~h})^{-\theta}\left(1 / \mathrm{P}_{\mathrm{j}}^{*}\right)^{-\theta} \mathrm{Y}_{\mathrm{j}}\right] & \mathrm{j}=\mathrm{D}, \mathrm{E}, \mathrm{N} \text { (for CCP) }
\end{aligned}
$$


The first order conditions - (9), (10) and (11) - are identical for all households in the home country; analogous equations hold for foreign households. Thus, we can focus on a symmetric equilibrium in which household variables are equal to aggregate variables: ${ }^{11} C_{j}(h)=C_{j}=Y_{j}=Y_{j}(h)$ for $j=N, D ; C_{E^{*}}(h)=C_{E^{*}}=Y_{E^{*}}=Y_{E^{*}}\left(h^{*}\right) ; C_{j}\left(h^{*}\right)=C_{j}=Y_{j}=Y_{j}\left(h^{*}\right)$ for $j=N^{*}, D^{*}$; and $C_{E}\left(h^{*}\right)=$ $C_{E}=Y_{E}=Y_{E}(h)$. Also, $P_{j}(h)=P_{j}$ for $j=N, D, E$ and $P_{j}^{*}\left(h^{*}\right)=P_{j}^{*}$ for $j=N^{*}, D^{*}, E^{*}$.

We will assume that governments return seigniorage revenues to the households:

(12) $\mathrm{M}-\mathrm{M}_{0}=-\mathrm{T}$ and $\mathrm{M}^{*}-\mathrm{M}_{0}^{*}=-\mathrm{T}^{*}$.

Moreover, home currency prices translate directly to foreign currency prices:

(13) $\mathrm{P}_{\mathrm{j}}=\mathrm{SP}_{\mathrm{j}}^{*}$ for all $\mathrm{j}$.

And finally, since there is no capital mobility, trade must be balanced in equilibrium: ${ }^{12}$

(14) $\mathrm{P}_{\mathrm{E}^{*}} \mathrm{C}_{\mathrm{E}^{*}}=\mathrm{P}_{\mathrm{E}} \mathrm{C}_{\mathrm{E}}$.

The fixed and flex-price equilibria can be calculated from the following equations: ${ }^{13}$

(15) $\mathrm{PC}=3 \mathrm{P}_{\mathrm{D}} \mathrm{C}_{\mathrm{D}}=3 \mathrm{P}_{\mathrm{E}^{*}} \mathrm{C}_{\mathrm{E}^{*}}=3 \mathrm{P}_{\mathrm{N}} \mathrm{C}_{\mathrm{N}}$ and $\mathrm{P}_{\mathrm{D}^{*}}^{*} \mathrm{C}_{\mathrm{D}^{*}}=\mathrm{P}_{\mathrm{E}}^{*} \mathrm{C}_{\mathrm{E}}=\mathrm{P}_{\mathrm{N}^{*}}^{*} \mathrm{C}_{\mathrm{N}^{*}}=1 / 3 \mathrm{P}^{*} \mathrm{C}^{*}$

(16) $(\mathrm{M} / \mathrm{P})^{v}=\mathrm{C}$ and $\left(\mathrm{M}^{*} / \mathrm{P}^{*}\right)^{v}=\mathrm{C}^{*}$

(17) flex $_{\mathrm{j}} \mathrm{Y}_{\mathrm{j}} / \mathrm{Z}_{\mathrm{j}}=1 / 3 \mu \quad \mathrm{j}=\mathrm{N}, \mathrm{D}, \mathrm{E}$ and $\mathrm{N}^{*}, \mathrm{D}^{*}, \mathrm{E}^{*}$

$(17)_{\text {fixed }} \mathrm{E}\left[\mathrm{Y}_{\mathrm{j}} / \mathrm{Z}_{\mathrm{j}}\right]=1 / 3 \mu \quad \mathrm{j}=\mathrm{N}, \mathrm{D}, \mathrm{E}$ and $\mathrm{N}^{*}, \mathrm{D}^{*}, \mathrm{E}^{*}$ (for both PCP and CCP).

In the flex-price solution, employment levels $\left(\mathrm{Y}_{\mathrm{j}} / \mathrm{Z}_{\mathrm{j}}\right)$ are fixed, and productivity shocks pass directly to output and consumption. In the fixed-price solutions (PCP or CCP), expected employment levels are fixed.

\section{Macroeconomic Interdependence in the Workhorse Model}

There is macroeconomic interdependence in the flex-price solution, but everything of interest 
for welfare is determined in equation $(17)_{\text {flex }}$ by the productivity shocks. The flex-price solution is of little interest - other than as a benchmark - in a study of policy coordination. In the fixed-price solutions, we shall see that $(17)_{\text {fixed }}$ determines the commodity prices, while aggregate demand equations (15) and (16) - determines consumption and employment. In these solutions, there is a role for monetary policy, and a potential need for policy coordination. And it is now obvious that analyzing macroeconomic interdependence is greatly simplified by the assumptions of constant expenditure shares and $\log$ utility of money $(v=1)$.

First, we show how the exchange rate is determined, and how commodity prices are set in the fixed-price solutions. Then, we can study the interdependence of employment and consumption. Exchange Rate Determination in the Workhorse Model:

The three characteristics that define the Workhorse Model - (C1) current account balance, (C2) constant expenditure shares, and (C3) log utility of money (or $v=1)$ - imply a very rudimentary theory of exchange rate determination:

Proposition 1: Exchange Rate Determination -

i. $(\mathrm{C} 1)$ and (C2) imply $\mathrm{S}=\mathrm{M}^{v} \mathrm{P}^{1-v} / \mathrm{M}^{* v} \mathrm{P}^{* 1-v}$.

ii. (C1), (C2) and (C3) imply $\mathrm{S}=\mathrm{M} / \mathrm{M}^{*}$.

Proof:

$1 / 3 \mathrm{M}^{v} \mathrm{P}^{1-v}={ }_{1}^{3} / 3 \mathrm{PC}_{=}^{2} \mathrm{P}_{\mathrm{E}^{*}} \mathrm{C}_{\mathrm{E}^{*}=} \mathrm{SP}_{\mathrm{E}}^{*} \mathrm{C}_{\mathrm{E}}^{*}=\mathrm{S} 1 / 3 \mathrm{P}^{*} \mathrm{C}^{*} \stackrel{3}{=} \mathrm{S}^{1} 1 / 3 \mathrm{M}^{* v} \mathrm{P}^{* 1-v}$

trade balance, (14), implies equality 1; constant expenditure shares, (7) implies equality 2; and money market equilibrium, (16) implies equality 3 . This establishes i. Adding the log utility of money (or $v=1$ ) establishes ii.

In the Workhorse Model, exchange rates do not depend on productivity or consumption or 
output. They do not depend on whether prices are fixed or flexible. They just fluctuate with the ratio of the money supplies. ${ }^{14}$ Moreover, this result does not depend upon how the three characteristics - (C1), (C2) \& (C3) - came about. In our model, (C1) and (C2) are due to the log utility of consumption and the Cobb-Douglas aggregator for the composite good, and (C3) is due to the log utility of money. But, any model that exhibits these properties will embody this very rudimentary theory of exchange rate determination. As we shall see, this plays a large role in what follows.

\section{Commodity Price Determination in the Fixed-Price Solutions:}

Commodity prices are found by substituting (15) and (16) into (17) $)_{\text {fixed }}$. Here, we do have to distinguish between price setting policies. Under PCP, home households set $\mathrm{P}_{\mathrm{N}}, \mathrm{P}_{\mathrm{D}}$ and $\mathrm{P}_{\mathrm{E}}$; under CCP, they set $\mathrm{P}_{\mathrm{N}}, \mathrm{P}_{\mathrm{D}}$ and $\mathrm{P}_{\mathrm{E}}^{*}$. Letting $v=1$, we have:

$(18)_{P C P} P_{j}=\mu E\left[M / Z_{j}\right]$ for $j=N, D, P_{E}=\mu E\left[S M^{*} / Z_{E}\right]$ and $P_{E}^{*}=P_{E} / S$

$$
\mathrm{P}_{\mathrm{j}}^{*}=\mu \mathrm{E}\left[\mathrm{M}^{*} / \mathrm{Z}_{\mathrm{j}}\right] \text { for } \mathrm{j}=\mathrm{N}^{*}, \mathrm{D}^{*}, \mathrm{P}_{\mathrm{E}^{*}}^{*}=\mu \mathrm{E}\left[\mathrm{M} / \mathrm{SZ} \mathrm{E}_{\mathrm{E}^{*}}\right] \text { and } \mathrm{P}_{\mathrm{E}^{*}}=\mathrm{SP}_{\mathrm{E}^{*}}^{*}
$$

$(18)_{C C P} P_{j}=\mu E\left[M / Z_{j}\right]$ for $j=N, D, E^{*}$ and $P_{j}^{*}=\mu E\left[M^{*} / Z_{j}\right]$ for $j=N^{*}, D^{*}, E$

$\mathrm{O} \& \mathrm{Rb}, \mathrm{C} \& \mathrm{~Pb}$ and Devereux and Engel (2000) have emphasized the fact that the systematic components of monetary policy and the exchange rate regime can affect the level of commodity prices. The main point for us is simply to note the currency in which the various prices are set.

Consumption and Employment Determination under Producer Currency Pricing:

Under PCP, home households set $\mathrm{P}_{\mathrm{N}}, \mathrm{P}_{\mathrm{D}}$, and $\mathrm{P}_{\mathrm{E}}$, and foreign households set $\mathrm{P}_{\mathrm{N}^{*}}^{*}, \mathrm{P}_{\mathrm{D}^{*}}^{*}$ and $\mathrm{P}_{\mathrm{E}^{*}}^{*}$. Combining (15) and (16), and letting $v=1$ :

(19) $\mathrm{M}=3 \mathrm{P}_{\mathrm{N}} \mathrm{C}_{\mathrm{N}}=3 \mathrm{P}_{\mathrm{D}} \mathrm{C}_{\mathrm{D}}=3 \mathrm{SP}_{\mathrm{E}^{*}}^{*} \mathrm{C}_{\mathrm{E}^{*}}(=\mathrm{PC})$ and $\mathrm{M}^{*}=3 \mathrm{P}_{\mathrm{N}^{*}}^{*} \mathrm{C}_{\mathrm{N}^{*}}=3 \mathrm{P}_{\mathrm{D}^{*}}^{*} \mathrm{C}_{\mathrm{D}^{*}}=3\left(\mathrm{P}_{\mathrm{E}} / \mathrm{S}\right) \mathrm{C}_{\mathrm{E}}\left(=\mathrm{P}^{*} \mathrm{C}^{*}\right)$, and from Proposition 1: 
(20) $\mathrm{S}=\mathrm{M} / \mathrm{M}^{*}$.

These equations determine consumption in the Workhorse Model; output and employment follow immediately (since $C_{j}=Y_{j}$ and $N_{j}=Y_{j} / Z_{j}$ ). Productivity shocks do not appear in equations (19) or (20). Consumption and output are completely demand determined in both of the fixed-price solutions; productivity shocks are absorbed by employment levels. Recall that in the flex-price solution, employment was constant, while productivity shocks were absorbed by consumption levels.

How does monetary policy work with PCP? An increase in M induces a proportionate increase in total home expenditure, PC, and a proportionate increase in expenditure on each of the goods that home households consume. Since $\mathrm{P}_{\mathrm{N}}$ and $\mathrm{P}_{\mathrm{D}}$ are fixed, $\mathrm{C}_{\mathrm{N}}$ and $\mathrm{C}_{\mathrm{D}}$ have to rise. However, the nominal exchange rate depreciates in proportion with $\mathrm{M}$; so, $\mathrm{P}_{\mathrm{E}^{*}}$ increases in proportion with $\mathrm{M}$, and there is no effect on $\mathrm{C}_{\mathrm{E}^{*}} \cdot \mathrm{C}_{\mathrm{E}^{*}}\left(\right.$ and $\left.\mathrm{Y}_{\mathrm{E}^{*}}\right)$ is instead determined by the foreign money supply, $\mathrm{M}^{*}$, via its effect on the exchange rate. The model is symmetric; a change in $\mathrm{M}^{*}$ has analogous effects.

These results are summarized in Proposition 2, which follows directly from (19) and (20):

Proposition 2: Macroeconomic Interdependence in the Workhorse Model with PCP -

A. The Insulated Supply Side:

$$
\begin{aligned}
& Y_{N}=1 / 3\left(M / P_{N}\right), Y_{D}=1 / 3\left(M / P_{D}\right), Y_{E}=1 / 3\left(M / P_{E}\right) \\
& Y_{N^{*}}=1 / 3\left(M^{*} / P_{N^{*}}^{*}\right), Y_{D^{*}}=1 / 3\left(M^{*} / P_{D^{*}}^{*}\right), Y_{E^{*}}=1 / 3\left(M^{*} / P_{E^{*}}^{*}\right) \\
& N_{j}=Y_{j} / Z_{j} \text { for } j=N, D, E, N^{*}, D^{*} \text { and } E^{*} .
\end{aligned}
$$

B. The Quixotic Interdependence of Consumption:

$$
\begin{aligned}
& C_{N}=1 / 3\left(M / P_{N}\right), C_{D}=1 / 3\left(M / P_{D}\right), C_{E^{*}}=1 / 3\left(M^{*} / P_{E^{*}}^{*}\right) \\
& C_{N^{*}}=1 / 3\left(M^{*} / P_{N^{*}}^{*}\right), C_{D^{*}}=1 / 3\left(M^{*} / P_{D^{*}}^{*}\right), C_{E}=1 / 3\left(M / P_{E}\right)
\end{aligned}
$$

The three assumptions that characterize the Workhorse Model - a balanced current account, 
constant expenditure shares, and log utility of money - lead to a extremely tractable model, but they also lead to a model in which macroeconomic interdependence is rather limited and highly stylized. Domestic monetary policy controls consumption and output of the domestically produced goods, while foreign monetary policy controls consumption of the imported traded good. The exchange rate completely insulates the supply side of the economy - employment and output - from any shock emanating from abroad; neither foreign productivity shocks nor foreign monetary policy matter.

During the Bretton Woods era, the old Chicago School made similar claims when it was extolling the merits of a flexible exchange rate system. Mussa (1979) outlined the conditions under which the Chicago School's arguments would imply the complete insulation of domestic employment from foreign repercussions. Interestingly enough, they included the absence of capital mobility. Of course, the Chicago School was interested in identifying the assumptions that would lead to what it viewed as a desired result. The builders of the Workhorse Model were interested in identifying the assumptions that would lead to closed form solutions in a rather intractable environment. The insulating effect of flexible exchange rates portrayed in Proposition 2 will be viewed by some as collateral damage.

These results can of course be traced to the rudimentary theory of exchange rate determination embodied in the Workhorse Model (and described by Proposition 1). Relaxing just one assumption - letting $v$ deviate from 1 - equations (15) and (16) imply that both home and foreign monetary policy affect all of the variables of interest; see Appendix B for the details.

\section{Consumption and Employment Determination under Customer Currency Pricing:}

Under CCP, home households set $\mathrm{P}_{\mathrm{N}}, \mathrm{P}_{\mathrm{D}}$, and $\mathrm{P}_{\mathrm{E}}^{*}$, and foreign households set $\mathrm{P}_{\mathrm{N}^{*}}^{*}, \mathrm{P}_{\mathrm{D}^{*}}^{*}$ and $\mathrm{P}_{\mathrm{E}^{*}}$. Combining (15) and (16), and letting $v=1$, the demand conditions become: 
(21) $\mathrm{M}=3 \mathrm{P}_{\mathrm{N}} \mathrm{C}_{\mathrm{N}}=3 \mathrm{P}_{\mathrm{D}} \mathrm{C}_{\mathrm{D}}=3 \mathrm{P}_{\mathrm{E}^{*}} \mathrm{C}_{\mathrm{E}^{*}}$ and $\mathrm{M}^{*}=3 \mathrm{P}_{\mathrm{N}^{*}}^{*} \mathrm{C}_{\mathrm{N}^{*}}=3 \mathrm{P}_{\mathrm{D}^{*}}^{*} \mathrm{C}_{\mathrm{D}^{*}}=3 \mathrm{P}_{\mathrm{E}}^{*} \mathrm{C}_{\mathrm{E}}$.

These equations determine consumption (and output and employment) under CCP:

Proposition 3: Macroeconomic Interdependence in the Workhorse Model with CCP -

A. The Insulation of Consumption:

$$
\begin{aligned}
& C_{N}=1 / 3\left(M / P_{N}\right), C_{D}=1 / 3\left(M / P_{D}\right), C_{E^{*}}=1 / 3\left(M / P_{E^{*}}\right) ; \\
& C_{N^{*}}=1 / 3\left(M^{*} / P_{N^{*}}^{*}\right), C_{D^{*}}=1 / 3\left(M^{*} / P_{D^{*}}^{*}\right), C_{E}=1 / 3\left(M^{*} / P_{E}^{*}\right) .
\end{aligned}
$$

B. The Quixotic Interdependence on the Supply Side:

$$
\begin{aligned}
& Y_{N}=1 / 3\left(M / P_{N}\right), Y_{D}=1 / 3\left(M / P_{D}\right), Y_{E}=1 / 3\left(M^{*} / P_{E}^{*}\right) \\
& Y_{N^{*}}=1 / 3\left(M^{*} / P_{N^{*}}^{*}\right), Y_{D^{*}}=1 / 3\left(M^{*} / P_{D^{*}}^{*}\right), Y_{E^{*}}=1 / 3\left(M / P_{E^{*}}\right) \\
& N_{j}=Y_{j} / Z_{j} \text { for } j=N, D, E, N^{*}, D^{*} \text { and } E^{*} .
\end{aligned}
$$

With CCP, we have an inversion of the case with PCP: complete insularity of consumption, and what might be described as quixotic interdependence on the supply side of the economy.

\section{Policy Coordination in the Workhorse Model}

One might expect that there would be little need for policy coordination in a model that exhibits so little macroeconomic interdependence. And indeed, that is precisely what $\mathrm{O} \& \mathrm{Rb}$ and $\mathrm{C} \& \mathrm{~Pb}$ found when the productivity shocks are perfectly correlated across sectors in each country. Here, we will illustrate their result, and then we will provide counterexamples to the notion that the gains from coordination must necessarily be small, even in the Workhorse Model. But first, we must be specific about the goals of monetary policy.

The Goals of Monetary Policy:

Second generation models posit a representative household in each country, and the utility 
of the representative household provides a natural measure of national welfare. We will assume that the goal of monetary policy in each country is to maximize the utility if its representative household. That said, second generation models exhibit three well known distortions that would tempt a central bank to create surprise inflations or deflations: (1) monopolistic competition makes households set prices too high (or work to little); (2) the seigniorage tax makes households hold too little money; and (3) an appreciation of the terms of trade can increase real national income (or shift the work effort onto foreigners). The literature is split on how to deal with these temptations.

Much of the recent literature seems reluctant to revisit these old issues. It is common to eliminate the whole problem of seigniorage by simply ignoring the money term in the utility functions; the justification given is that seigniorage is a small component of government revenue (and therefore a small distortion) in OECD countries. It is also common to eliminate the possibility of monetary surprises by assuming that central banks are pre-committed to monetary policy rules. ${ }^{15}$ We will follow both of these practices, but for a somewhat different reason. Canzoneri and Henderson (1991) argued that the existence of ongoing conflicts - such as a terms of trade war - may well lead to large gains from policy coordination. The question we want to ask here is whether there can be large gains from coordination in "stabilization" games; McKibbin (1997) argued that large gains were not found in the first generation models.

To be precise, let $\mathrm{W} \equiv \mathrm{U}-\log (\mathrm{M} / \mathrm{P})$ and $\mathrm{W}^{*} \equiv \mathrm{U}^{*}-\log \left(\mathrm{M}^{*} / \mathrm{P}^{*}\right)$. We assume central banks pre-commit to money supply rules that maximize $E[W]$ and $E\left[W^{*}\right]$. In a Nash solution, the home central bank chooses a rule that maximizes $\mathrm{E}[\mathrm{W}]$ (conditional on the rule for $\mathrm{M}^{*}$ ) and the foreign central bank chooses a rule that maximizes $\left.\mathrm{E}_{\mathrm{W}}^{*}\right]$ (conditional on the rule for $\mathrm{M}$ ); in a Cooperative solution, the central banks together choose rules that maximize $\mathrm{E}[\mathrm{W}]+\mathrm{E}\left[\mathrm{W}^{*}\right]$. 
Once again, assumptions that characterize the Workhorse Model have strong implications. Letting small letters denote the logarithms of capital letters, equations (1) and (17) fixed imply: Proposition 4: Central Bank Objectives in the Workhorse model -

Central banks maximize the expected utility of consumption; the expected disutility of work is beyond their control: $\mathrm{E}[\mathrm{W}]=\mathrm{E}[\log (\mathrm{C})]-1 / \mu \& \mathrm{E}\left[\mathrm{W}^{*}\right]=\mathrm{E}\left[\log \left(\mathrm{C}^{*}\right)\right]-1 / \mu$. The expected disutility of work is constant (and equal to $1 / \mu$ ) in the fixed-price solutions; this is a strong implication of a seemingly innocent assumption in the Workhorse Model - the log utility of consumption. ${ }^{16,17}$ Central banks do not try to "stabilize" the supply side of the economy. This is of course a major departure from the objectives postulated in the first generation models.

Since we assume that central banks maximize $\mathrm{E}[\mathrm{W}]$ and $\mathrm{E}\left[\mathrm{W}^{*}\right]$, it seems natural to assume that the productivity shocks are log-normally distributed. In this case, the model yields exact solutions for all of the variables if interest (including $\mathrm{E}[\mathrm{W}]$ and $\mathrm{E}\left[\mathrm{W}^{*}\right]$ ), and tractability was the main reason for the strong assumptions that characterize the Workhorse Model. ${ }^{18,19}$ Letting V[· $]$ denote a variance, letting small letters represent the logarithms of capital letters, and letting hats $\left(^{\wedge}\right)$ denote flex-price values, we have:

Lemma 1: Reduced Forms for Expected Consumption in the Workhorse Model If productivity shocks are log-normally distributed, then with PCP:

$$
\begin{aligned}
& \mathrm{E}\left(\mathrm{c}_{\mathrm{N}}\right)=\mathrm{E}\left(\hat{\mathrm{y}}_{\mathrm{N}}\right)-1 / 2 \mathrm{~V}\left[\mathrm{~m}-\mathrm{z}_{\mathrm{N}}\right], \mathrm{E}\left(\mathrm{c}_{\mathrm{D}}\right)=\mathrm{E}\left(\hat{\mathrm{y}}_{\mathrm{D}}\right)-1 / 2 \mathrm{~V}\left[\mathrm{~m}-\mathrm{z}_{\mathrm{D}}\right], \mathrm{E}\left(\mathrm{c}_{\mathrm{E}^{*}}\right)=\mathrm{E}\left(\hat{\mathrm{y}}_{\mathrm{E}^{*}}\right)-1 / 2 \mathrm{~V}\left[\mathrm{~m}^{*}-\mathrm{z}_{\mathrm{E}^{*}}\right] \\
& \mathrm{E}\left(\mathrm{c}_{\mathrm{N}^{*}}\right)=\mathrm{E}\left(\hat{\mathrm{y}}_{\mathrm{N}^{*}}\right)-1 / 2 \mathrm{~V}\left[\mathrm{~m}^{*}-\mathrm{z}_{\mathrm{N}^{*}}\right], \mathrm{E}\left(\mathrm{c}_{\mathrm{D}^{*}}\right)=\mathrm{E}\left(\hat{\mathrm{y}}_{\mathrm{D}^{*}}\right)-1 / 2 \mathrm{~V}\left[\mathrm{~m}^{*}-\mathrm{z}_{\mathrm{D}^{*}}\right], \mathrm{E}\left(\mathrm{c}_{\mathrm{E}}\right)=\mathrm{E}\left(\hat{\mathrm{y}}_{\mathrm{E}}\right)-1 / 2 \mathrm{~V}\left[\mathrm{~m}-\mathrm{z}_{\mathrm{E}}\right]
\end{aligned}
$$
with CCP:

$$
\begin{aligned}
& \mathrm{E}\left(\mathrm{c}_{\mathrm{N}}\right)=\mathrm{E}\left(\hat{\mathrm{y}}_{\mathrm{N}}\right)-1 / 2 \mathrm{~V}\left[\mathrm{~m}-\mathrm{z}_{\mathrm{N}}\right], \mathrm{E}\left(\mathrm{c}_{\mathrm{D}}\right)=\mathrm{E}\left(\hat{\mathrm{y}}_{\mathrm{D}}\right)-1 / 2 \mathrm{~V}\left[\mathrm{~m}-\mathrm{z}_{\mathrm{D}}\right], \mathrm{E}\left(\mathrm{c}_{\mathrm{E}^{*}}\right)=\mathrm{E}\left(\hat{\mathrm{y}}_{\mathrm{E}^{*}}\right)-1 / 2 \mathrm{~V}\left[\mathrm{~m}-\mathrm{z}_{\mathrm{E}^{*}}\right] \\
& \mathrm{E}\left(\mathrm{c}_{\mathrm{N}^{*}}\right)=\mathrm{E}\left(\hat{\mathrm{y}}_{\mathrm{N}^{*}}\right)-1 / 2 \mathrm{~V}\left[\mathrm{~m}^{*}-\mathrm{z}_{\mathrm{N}^{*}}\right], \mathrm{E}\left(\mathrm{c}_{\mathrm{D}^{*}}\right)=\mathrm{E}\left(\hat{\mathrm{y}}_{\mathrm{D}^{*}}\right)-1 / 2 \mathrm{~V}\left[\mathrm{~m}^{*}-\mathrm{z}_{\mathrm{D}^{*}}\right], \mathrm{E}\left(\mathrm{c}_{\mathrm{E}}\right)=\mathrm{E}\left(\hat{\mathrm{y}}_{\mathrm{E}}\right)-1 / 2 \mathrm{~V}\left[\mathrm{~m}^{*}-\mathrm{z}_{\mathrm{E}}\right]
\end{aligned}
$$


Proof:

$(17)_{\text {flex }} \Rightarrow \hat{y}_{j}=\log (1 / 3 \mu)+z_{j}$ for $j=N, D, E, N^{*}, D^{*} \& E^{*}$

$\log$-normality and $(17)_{\text {fixed }} \Rightarrow \log \left\{\mathrm{E}\left[\mathrm{Y}_{\mathrm{j}} / \mathrm{Z}_{\mathrm{j}}\right]\right\}=\mathrm{E}\left[\mathrm{y}_{\mathrm{j}}-\mathrm{z}_{\mathrm{j}}\right]+1 / 2 \mathrm{~V}\left[\mathrm{y}_{\mathrm{j}}-\mathrm{z}_{\mathrm{j}}\right]=\log (1 / 3 \mu)$

so, $E\left(y_{j}\right)=\log (1 / 3 \mu)+E\left(z_{j}\right)-1 / 2 V\left[y_{j}-z_{j}\right]=E\left(\hat{y}_{j}\right)-1 / 2 V\left[y_{j}-z_{j}\right]$

In equilibrium $y_{j}=c_{j}$, and the reduced forms for the $c_{j}$ are given in Proposition 2.

Proposition 4 and Lemma 1 enable us to derive exact solutions for national welfare. With PCP, the central banks want to maximize:

$$
\begin{aligned}
& \mathrm{E}[\mathrm{W}]=\mathrm{E}[\hat{\mathrm{W}}]-1 / 2\left\{\mathrm{~V}\left[\mathrm{~m}-\mathrm{z}_{\mathrm{N}}\right]+\mathrm{V}\left[\mathrm{m}-\mathrm{z}_{\mathrm{D}}\right]+\mathrm{V}\left[\mathrm{m}^{*}-\mathrm{z}_{\mathrm{E}^{*}}\right]\right\} \\
& \mathrm{E}\left[\mathrm{W}^{*}\right]=\mathrm{E}\left[\mathrm{W}^{*}\right]-1 / 2\left\{\mathrm{~V}\left[\mathrm{~m}^{*}-\mathrm{z}_{\mathrm{N}^{*}}\right]+\mathrm{V}\left[\mathrm{m}^{*}-\mathrm{z}_{\mathrm{D}^{*}}\right]+\mathrm{V}\left[\mathrm{m}-\mathrm{z}_{\mathrm{E}}\right]\right\}
\end{aligned}
$$

With CCP, the central banks want to maximize:

(23) $\mathrm{E}[\mathrm{W}]=\mathrm{E}[\hat{\mathrm{W}}]-1 / 2\left\{\mathrm{~V}\left[\mathrm{~m}-\mathrm{z}_{\mathrm{N}}\right]+\mathrm{V}\left[\mathrm{m}-\mathrm{z}_{\mathrm{D}}\right]+\mathrm{V}\left[\mathrm{m}-\mathrm{z}_{\mathrm{E}^{*}}\right]\right\}$

$$
\mathrm{E}\left[\mathrm{W}^{*}\right]=\mathrm{E}\left[\hat{\mathrm{W}}^{*}\right]-1 / 2\left\{\mathrm{~V}\left[\mathrm{~m}^{*}-\mathrm{z}_{\mathrm{N}^{*}}\right]+\mathrm{V}\left[\mathrm{m}^{*}-\mathrm{z}_{\mathrm{D}^{*}}\right]+\mathrm{V}\left[\mathrm{m}^{*}-\mathrm{z}_{\mathrm{E}}\right]\right\}
$$

In either case, the best that the monetary policy can do - individually or collectively - is to eliminate the variances and bring about the flex-price solution. As O\&Rb have noted, the flex-price solution is constrained Pareto efficient in the Workhorse Model. ${ }^{20}$

\section{Is There a Role for Policy Coordination in the Workhorse Model?}

In Section III, we showed that macroeconomic interdependence is rather limited in the Workhorse Model. Here, we have to differentiate between the two pricing policies, PCP and CCP. With PCP, Proposition 2 states that the supply side of the economy is completely insulated; the foreign central bank can not help the home central bank stabilize it's supply side. However, Proposition 4 states that the expected disutility of liesure is fixed, and - in contrast with the first generation models - central banks are not concerned with the supply side of the economy; central 
banks maximize the expected utility of consumption. From Lemma 1, we see that foreign monetary policy does affect domestic consumption of the imported good; in fact, the foreign money supply is the only policy instrument that affects import consumption. So, policy coordination may actually play an important role in the Workhorse Model with PCP.

By contrast, with CCP, Proposition 3 states that domestic consumption is completely insulated from foreign monetary policy. The foreign central bank can not help the home central bank increase the expected value of domestic consumption. As $\mathrm{C} \& \mathrm{~Pb}$ have shown, there is no need for policy coordination in the Workhorse Model in this case. ${ }^{21} \mathrm{We}$ will not consider CCP further.

Returning to $\mathrm{PCP}$, despite our earlier comments, both $\mathrm{O} \& \mathrm{Rb}$ and $\mathrm{C} \& \mathrm{~Pb}$ found that there is no need for policy coordination in the Workhorse Model. What accounts for their results? Both $\mathrm{O} \& \mathrm{Rb}$ and $\mathrm{C} \& \mathrm{~Pb}$ assumed that productivity shocks are perfectly correlated across sectors within a given country; in effect, they have a single productivity shock in each country: $\mathrm{z} \equiv \mathrm{z}_{\mathrm{N}}=\mathrm{z}_{\mathrm{D}}=\mathrm{z}_{\mathrm{E}}$ and $\mathrm{Z}^{*} \equiv \mathrm{z}_{\mathrm{N}^{*}}=\mathrm{z}_{\mathrm{D}^{*}}=\mathrm{z}_{\mathrm{E}^{*}}$. The central bank objectives - equations (22) - reduce to maximizing:

(24) $\mathrm{E}[\mathrm{W}]=\mathrm{E}[\hat{\mathrm{W}}]-1 / 2\left\{\mathrm{~V}[\mathrm{~m}-\mathrm{z}]+\mathrm{V}[\mathrm{m}-\mathrm{z}]+\mathrm{V}\left[\mathrm{m}^{*}-\mathrm{z}^{*}\right]\right\}$

$$
\mathrm{E}\left[\mathrm{W}^{*}\right]=\mathrm{E}\left[\hat{\mathrm{W}}^{*}\right]-1 / 2\left\{\mathrm{~V}\left[\mathrm{~m}^{*}-\mathrm{z}^{*}\right]+\mathrm{V}\left[\mathrm{m}^{*}-\mathrm{z}^{*}\right]+\mathrm{V}[\mathrm{m}-\mathrm{z}]\right\}
$$

Here, Nash and Cooperative policy rules coincide: $\mathrm{m}=\mathrm{z}$ and $\mathrm{m}^{*}=\mathrm{z}^{*}$. Each central banks moves its money supply in proportion with its domestic productivity shock, and this brings about the flexprice solution. ${ }^{22}$ As has already been noted, the flex-price solution is the best that the central banks can do, acting individually or collectively.

When productivity shocks are perfectly correlated across sectors, the central banks have a sufficient number of properly placed instruments to meet all of their objectives in a Nash solution. For a coordination problem to exist, tradeoffs must remain in the Nash solution. From a modeling 
point of view, there is an obvious way to introduce tradeoffs in the setup we have already laid out: simply relax the assumption that the sectoral productivity shocks are perfectly correlated. This would certainly be motivated by empirical work on the Balassa-Samuelson hypothesis; for example, Canzoneri, Cumby and Diba (1999) show that the time series processes generating productivity shocks in the traded and non-traded goods sectors are quite different. We will explore this possibility in the next subsection.

Another way of introducing a tradeoff is suggested by Erceg, Henderson and Levin (2000) (in the closed economy literature): decentralize production and introduce asymmetries in nominal inertia across sectors. This would produce tradeoffs even when the productivity shocks are perfectly correlated in each country. Because of space limitations, we will not model these tradeoffs in detail. However, we can explain how they would come about.

Suppose for example that in the non-traded good sector, prices are set one period in advance while wages are flexible. In the traded good sector, we have just the opposite: wages are set one period in advance while prices are flexible. We can retain the assumption that productivity shocks are perfectly correlated across sectors. In the traded good sector, firms will set prices at a markup over marginal cost: $\mathrm{P}_{\mathrm{T}}=\mu\left(\mathrm{W}_{\mathrm{T}} / \mathrm{Z}\right)$, where $\mathrm{W}_{\mathrm{T}}$ is the preset wage and $\mu$ is the markup factor. In this sector, prices will move in inverse proportion with the productivity shock; constant expenditure shares will then imply that consumption and output move in proportion with the productivity shock. This is exactly what would be called for by the flex-wage/price solution; there is no need for monetary policy to do anything in this sector. ${ }^{23}$ However, prices are fixed in the non-traded good sector, and (as above) the money supply would have to move in proportion with the productivity shock to bring about the flex-wage/price level of consumption and output in this sector. A single 
monetary policy could not simultaneously bring both sectors to their flex-wage/price solutions.

Yet another way of introducing a tradeoff into the Nash solution would be to model a separate cost to inflation, a cost that is not associated with the nominal inertia on the supply side. ${ }^{24}$ First generation models simply postulated an inflation goal. Second generation models impose the discipline that inflation costs have to be modeled, and not just asserted. One obvious possibility is to reintroduce seigniorage distortions; however, most of the new literature has resisted that approach, asserting that these are small. Feldstein (1998) may offer a more compelling approach to modeling separate costs for inflation. The lack of a separate inflation goal is likely to remain one of the most intriguing ways in which second generation models of policy coordination differ from the first generation models, and therefore a potential source of differences in conclusions.

As mentioned in the introduction, both $\mathrm{C} \& \mathrm{~Pb}$ and $\mathrm{O} \& \mathrm{Rb}$ extended the Workhorse Model in ways that introduced a tradeoff in the Nash solution. O\&Rb calculated four different solutions to their extended model: (1) a "no response" solution in which central banks hold their money supplies constant, (2) an "active stabilization" solution in which the central banks set their monetary policies to achieve the flex-price solution, (3) the Nash solution (as defined above), and (4) the Cooperative solution (as defined above). They then argued that for reasonable parameterizations of their model, the utility gains from cooperation are extremely small. ${ }^{25}$ More specifically, let $\mathrm{R}$ be the ratio of the gain from going from (2) (or (3)) to (4) to the gain from going from (1) to (2) (or (3)). O\&Rb showed that $\mathrm{R}$ was no bigger than 0.13 for values of the coefficient of relative risk aversion less than 8. Benigno (2000) analyzed the same question in a more general intertemporal model and came to much the same conclusion.

O\&Rb's finding is quite reminiscent of earlier analyses of first generation models. For ex- 
ample, Canzoneri and Edison (1990) used multipliers from the FRB's Multi-country Model to simulate various game situations; they found R-ratios of about 0.01. And, Canzoneri and Minford's (1988) analysis of the structure of first generation models suggested that the gains from coordination in those models must necessarily be small. More recently, McKibbin (1997) surveyed the literature on first generation models and reported a folk theorem to the effect that the gains from coordination are empirically small. In his words, "It appears from the evidence to date that the largest gains for the world economy are to be realized from some form of policy optimization at the individual economy level or the sensible choice of a policy regime given the nature of shocks expected to impinge on the world economy. Any additional gains from coordination of policies between economies have been found to be dwarfed by the potential gains from individual countries adjusting policies in a sensible manner."

So, the really interesting question here is whether the second generation models will exhibit any greater role for policy coordination than did the first. A serious answer to this question would require a realistically parameterizable model, and the Workhorse Model is arguably a long way away from that. However, in the next subsection, we use the Workhorse Model to present counterexamples to the notion that the gains from coordination must necessarily be small in second generation models.

\section{Gains From Coordination in the Workhorse Model with Sector Specific Productivity Shocks}

Now, we will relax the assumption that productivity shocks are perfectly correlated across the sectors within each country. As noted above, this is one way of introducing a tradeoff in the Nash solution; and this tradeoff may imply a role for policy coordination, even in the Workhorse Model which exhibits relatively little macroeconomic interdependence. 
Four special cases illustrate the breadth of results that are possible in second generation models of policy coordination. In the first case, productivity shocks are perfectly correlated across sectors each country; this is of course the case analyzed by $O \& \mathrm{Rb}$ and $\mathrm{C} \& \mathrm{~Pb}$. In the second case, shocks to the tradable good sector are much more important than shocks to the non-tradable good sector. In the third case, shocks to the non-tradable good sector are much more important than shocks to the tradable-good sectors. In the fourth case, shocks to the export sector are much more important than shocks to the other sectors. In each case, we calculate the R-ratio, the ratio of gains from coordination to the gains from simply reacting optimally to the shocks in a Nash solution.

Our results are summarized in the following proposition:

Proposition 5: Gains from Coordination in the Workhorse Model -

The R-ratio can be very small or very large depending on the size and correlations of the productivity shocks. The possibilities are illustrated by the following cases: Case $1(\mathrm{O} \& \mathrm{Rb}$ and $\mathrm{C} \& \mathrm{~Pb}): \mathrm{z}_{\mathrm{N}}=\mathrm{z}_{\mathrm{D}}=\mathrm{z}_{\mathrm{E}} \equiv \mathrm{z}$ and $\mathrm{z}_{\mathrm{N}^{*}}=\mathrm{z}_{\mathrm{D}^{*}}=\mathrm{z}_{\mathrm{E}^{*}} \equiv \mathrm{z}^{*} \Rightarrow \mathrm{R}=0$. Case 2: $\mathrm{z}_{\mathrm{D}}=\mathrm{z}_{\mathrm{E}} \equiv \mathrm{z}_{\mathrm{T}}, \mathrm{z}_{\mathrm{D}^{*}}=\mathrm{z}_{\mathrm{E}^{*}} \equiv \mathrm{z}_{\mathrm{T}^{*}}, \mathrm{~V}\left(\mathrm{z}_{\mathrm{T}}\right)=\mathrm{V}\left(\mathrm{z}_{\mathrm{T}^{*}}\right)=\sigma^{2}$ and $\mathrm{V}\left(\mathrm{z}_{\mathrm{N}}\right)=\mathrm{V}\left(\mathrm{z}_{\mathrm{N}^{*}}\right)=0 \Rightarrow \mathrm{R}=1 / 15$ Case 3: $\mathrm{V}\left(\mathrm{z}_{\mathrm{N}}\right)=\mathrm{V}\left(\mathrm{z}_{\mathrm{N}^{*}}\right)=\sigma^{2}$ and $\mathrm{V}\left(\mathrm{z}_{\mathrm{D}}\right)=\mathrm{V}\left(\mathrm{z}_{\mathrm{E}}\right)=\mathrm{V}\left(\mathrm{z}_{\mathrm{D}^{*}}\right)=\mathrm{V}\left(\mathrm{z}_{\mathrm{E}^{*}}\right)=0 \Rightarrow \mathrm{R}=1 / 3$. Case 4: $\mathrm{V}\left(\mathrm{z}_{\mathrm{E}}\right)=\mathrm{V}\left(\mathrm{z}_{\mathrm{E}^{*}}\right)=\sigma^{2}$ and $\mathrm{V}\left(\mathrm{z}_{\mathrm{N}}\right)=\mathrm{V}\left(\mathrm{z}_{\mathrm{D}}\right)=\mathrm{V}\left(\mathrm{z}_{\mathrm{N}^{*}}\right)=\mathrm{V}\left(\mathrm{z}_{\mathrm{D}^{*}}\right)=0 \Rightarrow \mathrm{R}=\infty$. Proof: The calculations are a straightforward; Appendix A provides the details. Case 1 is the $\mathrm{O} \& \mathrm{Rb}-\mathrm{C} \& \mathrm{~Pb}$ result, which was discussed in the last subsection. Nash and Cooperative solutions coincide; there are no gains from coordination. Case 2 does show gains from coordination, but they are quite small. They are on the order of magnitude of those reported in by $\mathrm{O} \& \mathrm{Rb}$ for their extended model, and those reported by McKibbin (1997) in his survey of the first generation models. Case 3 shows gains from coordination that would appear to be important, and Case 4 shows large gains that are unambiguously large. 
Cases 3 and 4 are counterexamples to the notion that the gains from coordination must necessarily be small in the second generation models of policy coordination. Canzoneri and Minford (1988) suggested there was something about the structure of first generation models that limited the scope for policy coordination. That does not seem to be the case with second generation models.

\section{Conclusion}

O\&Ra and C\&Pa developed a Workhorse Model that paved the way for a second generation of policy coordination models incorporating optimizing households, monopolistic competition and nominal inertia. O\&Rb asked the question: “Do We Really Need a New International Monetary Compact?" Based on their analysis of an extension of the Workhorse Model, they concluded: "Surprisingly, the answer may be no." We have argued to the contrary that policy coordination may be more important in second generation models than it ever was in the first generation models.

Our argument was based on several counterexamples to the notion that the gains from coordination must necessarily be small in second generation models. (This notion was given the status of a folk theorem from the literature on first generation models.) Our counterexamples ride on asymmetries in sectoral productivity and nominal inertia. But, our examples are only suggestive of the need for policy coordination; they need to be backed by stronger empirical evidence on the asymmetries. Which sectors show more nominal wage stickiness? Which sectors show more nominal price stickiness? How pronounced is the asymmetry? The Balassa-Samuelson literature provides evidence on productivity differentials across traded and non-traded goods sectors, but this may not be the right sectoral breakdown. Which sectors show the most asymmetry? And how pronounced is the asymmetry? More empirical work on these asymmetries is needed before we can give a serious answer to the question Obstfeld and Rogoff have asked. This is what's yet to come. 


\section{References:}

Benigno, Gianluca and Pierpaolo Benigno, "Price Stability as a Nash Equilibrium in Monetary Open-Economy Models, mimeo, October, 2000.

, "Implementing Monetary Policy Cooperation through Inflation Targeting," mimeo Oct. 2001.

Benigno, Pierpaolo, "Price Stability with Imperfect Financial Integration," mimeo, May 2000.

Canzoneri, Matthew, Robert Cumby and Behzad Diba, "Notes On Models With Monopolistic Competition and Sticky Prices (and/or Wages)," 2001. These notes are available on Matthew Canzoneri's web page.

, "Relative Labor Productivity and the Real Exchange Rate in the Long Run: Evidence for a Panel of OECD Countries," Journal of International Economics, 47, 1999, p. 245-266.

Canzoneri, Matthew and Dale Henderson, Noncooperative Monetary Policies in Interdependent Economies, MIT Press, 1991.

Canzoneri, Matthew and Hali Edison, "A New Interpretation of the Coordination Problem and Its Empirical Significance", in Peter Hooper et ali. (ed) Monetary Aggregates and Financial Sector Behavior in Interdependent Economies, Board of Governors of the Federal Reserve System, 1990, 299-433.

Canzoneri, Matthew and JoAnna Gray, "Monetary Policy Games and the Consequences of Non-cooperative Behavior", International Economic Review, October, 1985, 547-564.

Canzoneri, Matthew and Patrick Minford, "When International Policy Coordination Matters: an Empirical Analysis," Applied Economics, 20, 1988, 1137-1154.

Chari, VV, Patrick Kehoe and Ellen McGrattan, "Sticky Price Models of the Business Cycle: Can the Contract Multiplier Solve the Persistence Problem?,’FRB of Minn. Staff Report, 1996.

Clarida, Richard, Mark Gertler and Jordi Gali, “A Simple Framework for International Monetary Policy Analysis", mimeo (2001).

Corsetti, Giancarlo and Paolo Pesenti, "Welfare and Macroeconomic Interdependence," Quarterly Journal of Economics, 116 (2), May 2001a, 421-446.

Corsetti, Giancarlo and Paolo Pesenti, "International Dimensions of Optimal Monetary Policy," FRBNY Staff Report No. 124, April, 2001b.

Devereux, Michael and Charles Engel, "Monetary Policy in the Open Economy Revisited: Price Setting and Exchange Rate Flexibility," NBER Working Paper No. 7665, 2000.

, "Endogenous Currency of Price Setting in a Dynamic Open Economy Model", 2001.

Erceg, Christopher, Dale Henderson, Andrew Levin, "Optimal Monetary Policy with Staggered Wage and Price Contracts", Journal of Monetary Economics, 46, 2000.

Feldstein, Martin, "The Costs and Benefits of Going from Low Inflation to Price Stability," in Monetary Policy and Inflation, C. Romer and D. Romer (eds.), Chicago: University of Chicago Press, 1998. 
Goodfriend, Marvin and Robert King, "The New Neoclassical Synthesis and the Role of Monetary Policy," NBER Macroeconomics Annual, MIT Press, 1997, pg. 223-283.

Hamada, Koichi, "Alternative Exchange Rate Systems and the interdependence of Monetary Policies," in Robert Aliber, ed., National Monetary Policies and the International Financial System, University of Chicago Press, Chicago, 1974.

, Macroeconomic Strategy Coordination under Alternative Exchange Rates,” in Rudiger Dornbusch and Jacob Frenkel, eds., International Economic Policy, Johns Hopkins University Press, Baltimore, 1979.

Henderson, Dale and Jinill Kim, "Exact Utilities under Alternative Rules in a Simple Macro Model with Optimizing Agents, International Tax and Public Finance, 6, 4, 1999.

Ireland, Peter, “The Role of Countercyclical Monetary Policy," Journal of Political Economy, 4, 1996, pg. 704-723.

King, Robert and Alexander Wolman, "What Should the Monetary Authority Do When Prices are Sticky?", in John Taylor (ed), Monetary Policy Rules, Chicago Press, 1999.

McKibbin, Warwick, "Empirical Evidence on International Economic Policy Coordination," Chapter 5 of Fratianni, M. , Salvatore D. and J. Von Hagen (eds) Handbook of Comparative Economic Policies volume 5: Macroeconomic Policy in Open Economies, Greenwood Press, 1997, pp148-176.

Mussa, Michael, "Macroeconomic Interdependence and the Exchange Rate Regime," Chapter 5 in Rudiger Dornbusch and Jacob Frenkel, eds., International Economic Policy, Johns Hopkins University Press, Baltimore, 1979.

Obstfeld, Maurice and Kenneth Rogoff, "New Directions for Stochastic Open Economy Models," Journal of International Economics, 50, 2000a, 117-153.

Obstfeld, Maurice and Kenneth Rogoff, "Do We Really Need a New International Monetary Compact," NBER Working Paper No. 7864, 2000 b.

Oudiz, Gilles and Jeffery Sachs, "Macroeconomic Policy Coordination Among the Industrial Economies, Brookings Papers on Economic Activity, no. 1, 1 - 64.

Rotemberg, Julio and Michael Woodford, “ An Optimization Based Framework for the Evaluation of Monetary Policy," in Ben Bernanke and Julio Rotemberg (eds), NBER Macroeconomics Annual, MIT Press, 1997, p. 297 - 346.

, "Interest Rate Rules in an Estimated Sticky Price Model,"in John Taylor (ed), Monetary Policy Rules, U. of Chicago Press, 1999.

Sohmen, Egon, Flexible Exchange Rates: Theory and Controversy, University of Chicago Press, Chicago, 1961. 


\section{Appendix A: Proof of Proposition 5.}

In what follows, we can lighten the notation by redefining the central banks' objectives in terms of losses; in particular, equations (22) imply that the central banks want to minimize:

(A1) $\Lambda \equiv \mathrm{V}\left[\mathrm{m}-\mathrm{z}_{\mathrm{N}}\right]+\mathrm{V}\left[\mathrm{m}-\mathrm{z}_{\mathrm{D}}\right]+\mathrm{V}\left[\mathrm{m}^{*}-\mathrm{z}_{\mathrm{E}^{*}}\right]$

$$
\Lambda^{*} \equiv\left[\mathrm{m}^{*}-\mathrm{z}_{\mathrm{N}^{*}}\right]+\mathrm{V}\left[\mathrm{m}^{*}-\mathrm{z}_{\mathrm{D}^{*}}\right]+\mathrm{V}\left[\mathrm{m}-\mathrm{z}_{\mathrm{E}}\right] .
$$

Then, the R-ratio can be written as:

(A2) $\mathrm{R}=\left(\Lambda_{\text {Nash }}-\Lambda_{\text {Cooperation }}-\right) /\left(\Lambda_{\text {No Response }}-\Lambda_{\text {Nash }}\right)$.

Proposition 5: Gains from Coordination in the Workhorse Model -

The gain ratio, $\mathrm{R}$, can be very small or very large depending on the size and correlations of the shocks. The possibilities are illustrated by the following cases:

Case $1(\mathrm{O} \& \mathrm{Rb}$ and $\mathrm{C} \& \mathrm{~Pb}): \mathrm{z}_{\mathrm{N}}=\mathrm{z}_{\mathrm{D}}=\mathrm{z}_{\mathrm{E}} \equiv \mathrm{z}$ and $\mathrm{z}_{\mathrm{N}^{*}}=\mathrm{z}_{\mathrm{D}^{*}}=\mathrm{z}_{\mathrm{E}^{*}} \equiv \mathrm{z}^{*} \Rightarrow \mathrm{R}=0$.

Case 2: $\mathrm{z}_{\mathrm{D}}=\mathrm{z}_{\mathrm{E}} \equiv \mathrm{z}_{\mathrm{T}}, \mathrm{z}_{\mathrm{D}^{*}}=\mathrm{z}_{\mathrm{E}^{*}} \equiv \mathrm{z}_{\mathrm{T}^{*}}, \mathrm{~V}\left(\mathrm{z}_{\mathrm{T}}\right)=\mathrm{V}\left(\mathrm{z}_{\mathrm{T}^{*}}\right)=\sigma^{2}$ and $\mathrm{V}\left(\mathrm{z}_{\mathrm{N}}\right)=\mathrm{V}\left(\mathrm{z}_{\mathrm{N}^{*}}\right)=0 \Rightarrow \mathrm{R}=1 / 15$

Case 3: $\mathrm{V}\left(\mathrm{z}_{\mathrm{N}}\right)=\mathrm{V}\left(\mathrm{z}_{\mathrm{N}^{*}}\right)=\sigma^{2}$ and $\mathrm{V}\left(\mathrm{z}_{\mathrm{D}}\right)=\mathrm{V}\left(\mathrm{z}_{\mathrm{E}}\right)=\mathrm{V}\left(\mathrm{z}_{\mathrm{D}^{*}}\right)=\mathrm{V}\left(\mathrm{z}_{\mathrm{E}^{*}}\right)=0 \Rightarrow \mathrm{R}=1 / 3$.

Case 4: $\mathrm{V}\left(\mathrm{z}_{\mathrm{E}}\right)=\mathrm{V}\left(\mathrm{z}_{\mathrm{E}^{*}}\right)=\sigma^{2}$ and $\mathrm{V}\left(\mathrm{z}_{\mathrm{N}}\right)=\mathrm{V}\left(\mathrm{z}_{\mathrm{D}}\right)=\mathrm{V}\left(\mathrm{z}_{\mathrm{N}^{*}}\right)=\mathrm{V}\left(\mathrm{z}_{\mathrm{D}^{*}}\right) \Rightarrow \mathrm{R}=\infty$.

Proof:

Case 1: Home central bank objective: $\operatorname{Min} \Lambda=V(m-z)+V(m-z)+V\left(m^{*}-z^{*}\right)$

Foreign central bank objective: $\operatorname{Min} \Lambda^{*}=V\left(m^{*}-z^{*}\right)+V\left(m^{*}-z^{*}\right)+V(m-z)$

By inspection that the Nash and Cooperative solutions are $\mathrm{m}=\mathrm{z}$ and $\mathrm{m}^{*}=\mathrm{z}^{*}$, and $\mathrm{R}=0$.

Case 2: Home central bank objective: $\operatorname{Min} \Lambda=V(m)+V\left(m-z_{T}\right)+V\left(m^{*}-z_{T^{*}}\right)$

Foreign central bank objective: $\operatorname{Min} \Lambda^{*}=\mathrm{V}\left(\mathrm{m}^{*}\right)+\mathrm{V}\left(\mathrm{m}^{*}-\mathrm{z}_{\mathrm{T}^{*}}\right)+\mathrm{V}\left(\mathrm{m}-\mathrm{z}_{\mathrm{T}}\right)$

It is clear that the central banks will not want to respond to foreign shocks, as this would just increase variances; so, let $\mathrm{m}=\gamma \mathrm{z}_{\mathrm{T}}$ and $\mathrm{m}^{*}=\gamma^{*} \mathrm{z}_{\mathrm{T}^{*}}$ :

Home central bank objective: $\operatorname{Min} \Lambda=\left[\gamma^{2}+(1-\gamma)^{2}+\left(1-\gamma^{*}\right)^{2}\right] \sigma^{2}$

Foreign central bank objective: $\operatorname{Min} \Lambda^{*}=\left[\gamma^{* 2}+\left(1-\gamma^{*}\right)^{2}+(1-\gamma)^{2}\right] \sigma^{2}$

Nash solution: $\gamma=\gamma^{*}=1 / 2 ; \Lambda=\Lambda^{*}=\left[1 / 2^{2}+1 / 2^{2}+1 / 2^{2}\right] \sigma^{2}=(3 / 4) \sigma^{2}$

Cooperative solution: $\gamma=\gamma^{*}=2 / 3 ; \Lambda=\Lambda^{*}=\left[(2 / 3)^{2}+(1 / 3)^{2}+(1 / 3)^{2}\right] \sigma^{2}=(2 / 3) \sigma^{2}$

No Response solution: $\gamma=\gamma^{*}=0 ; \Lambda=\Lambda^{*}=2 \sigma^{2}$

$\mathrm{R}=(1 / 12) /(5 / 4)=1 / 15$. 
Case 3: Home central bank objective: $\operatorname{Min} \Lambda=\mathrm{V}\left(\mathrm{m}-\mathrm{z}_{\mathrm{N}}\right)+\mathrm{V}(\mathrm{m})+\mathrm{V}\left(\mathrm{m}^{*}\right)$

Foreign central bank objective: $\operatorname{Min} \Lambda^{*}=\mathrm{V}\left(\mathrm{m}^{*}-\mathrm{z}_{\mathrm{N}^{*}}\right)+\mathrm{V}\left(\mathrm{m}^{*}\right)+\mathrm{V}(\mathrm{m})$

It is clear that central banks will not want to respond to the foreign shocks, as this would just increase variances. So, let $\mathrm{m}=\gamma \mathrm{z}_{\mathrm{N}}$ and $\mathrm{m}^{*}=\gamma^{*} \mathrm{z}_{\mathrm{N}^{*}}$ be the policy rules; then:

Home central bank objective: $\operatorname{Min} \Lambda=\left[(1-\gamma)^{2}+\gamma^{2}+\gamma^{* 2}\right] \sigma^{2}$

Foreign central bank objective: $\operatorname{Min} \Lambda^{*}=\left[\left(1-\gamma^{*}\right)^{2}+\gamma^{* 2}+\gamma^{2}\right] \sigma^{2}$

Nash solution: $\gamma=\gamma^{*}=1 / 2 ; \Lambda=\Lambda^{*}=\left[1 / 2^{2}+1 / 2^{2}+1 / 2^{2}\right] \sigma^{2}=(3 / 4) \sigma^{2}$

Cooperative solution: $\gamma=\gamma^{*}=1 / 3 ; \Lambda=\Lambda^{*}=\left[(2 / 3)^{2}+1 / 3^{2}+1 / 3^{2}\right] \sigma^{2}=(2 / 3) \sigma^{2}$;

No Response solution: $\gamma=\gamma^{*}=0 ; \Lambda=\Lambda^{*}=\sigma^{2}$;

$\mathrm{R}=(1 / 12) /(1 / 4)=1 / 3$.

Case 4: Home central bank objective: $\operatorname{Min} \Lambda=V(m)+V(m)+V\left(m^{*}-z^{*}\right)$

Foreign central bank objective: $\operatorname{Min} \Lambda^{*}=\mathrm{V}\left(\mathrm{m}^{*}\right)+\mathrm{V}\left(\mathrm{m}^{*}\right)+\mathrm{V}(\mathrm{m}-\mathrm{z})$

It is clear that the central banks will not want to respond to the foreign shocks, as this would just increase variances; so, let $\mathrm{m}=\gamma \mathrm{z}$ and $\mathrm{m}^{*}=\gamma^{*} \mathrm{z}^{*}$ :

No Response and Nash solutions: $\gamma=\gamma^{*}=0 ; \Lambda=\Lambda^{*}=\sigma^{2}$;

Cooperative solution: $\gamma=\gamma^{*}=1 / 3 ; \Lambda=\Lambda^{*}=\left[1 / 3^{2}+1 / 3^{2}+(2 / 3)^{2}\right] \sigma^{2}=(2 / 3) \sigma^{2}$; $\mathrm{R}=\infty$. 


\section{Appendix B: Solution under PCP when $v \neq 1$.}

Under PCP, $\mathrm{P}_{\mathrm{N}}, \mathrm{P}_{\mathrm{D}}$, and $\mathrm{P}_{\mathrm{E}}$ are set by home households, and $\mathrm{P}_{\mathrm{N}^{*}}^{*}, \mathrm{P}_{\mathrm{D}^{*}}^{*}$ and $\mathrm{P}_{\mathrm{E}^{*}}^{*}$ are set by foreign households. Combining (15) and (16), the home and foreign demand conditions become:

(B1) $\mathrm{M}^{v} \mathrm{P}^{(1-v)}=3 \mathrm{P}_{\mathrm{N}} \mathrm{C}_{\mathrm{N}}=3 \mathrm{P}_{\mathrm{D}} \mathrm{C}_{\mathrm{D}}=3 \mathrm{SP}_{\mathrm{E}^{*}}^{*} \mathrm{C}_{\mathrm{E}^{*}}$ and $\mathrm{M}^{* v} \mathrm{P}^{*(1-v)}=3 \mathrm{P}_{\mathrm{N}^{*}}^{*} \mathrm{C}_{\mathrm{N}^{*}}=3 \mathrm{P}_{\mathrm{D}^{*}}^{*} \mathrm{C}_{\mathrm{D}^{*}}=3 \mathrm{~S}\left(\mathrm{P}_{\mathrm{E}} / \mathrm{S}\right) \mathrm{C}_{\mathrm{E}}$ From (6), the price levels are given by:

(B2) $\mathrm{P}=3 \mathrm{P}_{\mathrm{D}}^{1 / 3}\left(\mathrm{SP}_{\mathrm{E}^{*}}^{*}\right)^{1 / 3} \mathrm{P}_{\mathrm{N}}^{1 / 3}$ and $\mathrm{P}^{*}=3 \mathrm{P}_{\mathrm{D}^{*}}^{* 1 / 3}\left(\mathrm{P}_{\mathrm{E}} / \mathrm{S}\right)^{1 / 3} \mathrm{P}_{\mathrm{N}^{*}}^{* 1 / 3}$

And from Proposition 1, the exchange rate is given by:

(B3) $\mathrm{S}=\mathrm{M}^{v} \mathrm{P}^{1-v} / \mathrm{M}^{* v} \mathrm{P}^{* 1-v}$.

These equations can be solved for the commodity consumption levels in each country; output and employment levels follow immediately ( since $\mathrm{C}_{\mathrm{j}}=\mathrm{Y}_{\mathrm{j}}$ and $\mathrm{N}_{\mathrm{j}}=\mathrm{Y}_{\mathrm{j}} / \mathrm{Z}_{\mathrm{j}}$ ).

Lemma 1 generalizes to:

Lemma 2: Reduced Forms for Expected Consumption in the Workhorse Model when $v \neq 1-$

$$
\begin{aligned}
& \mathrm{E}\left(\mathrm{c}_{\mathrm{N}}\right)=\mathrm{E}\left(\hat{\mathrm{y}}_{\mathrm{N}}\right)-1 / 2 \mathrm{~V}\left[v(v+2)(1+2 \mathrm{v})^{-1} \mathrm{~m}+v(v-1)(1+2 v)^{-1} \mathrm{~m}^{*}-\mathrm{z}_{\mathrm{N}}\right] \\
& \mathrm{E}\left(\mathrm{c}_{\mathrm{D}}\right)=\mathrm{E}\left(\hat{\mathrm{y}}_{\mathrm{D}}\right)-1 / 2 \mathrm{~V}\left[v(v+2)(1+2 \mathrm{v})^{-1} \mathrm{~m}+v(v-1)(1+2 v)^{-1} \mathrm{~m}^{*}-\mathrm{z}_{\mathrm{D}}\right] \\
& \mathrm{E}\left(\mathrm{c}_{\mathrm{E}^{*}}\right)=\mathrm{E}\left(\hat{\mathrm{y}}_{\mathrm{E}^{*}}\right)-1 / 2 \mathrm{~V}\left[v(v-1)(1+2 v)^{-1} \mathrm{~m}+v(2+v)(1+2 v)^{-1} \mathrm{~m}^{*}-\mathrm{z}_{\mathrm{E}^{*}}\right] \\
& \mathrm{E}\left(\mathrm{c}_{\mathrm{N}^{*}}^{*}\right)=\mathrm{E}\left(\hat{\mathrm{y}}_{\mathrm{N}^{*}}\right)-1 / 2 \mathrm{~V}\left[v(v+2)(1+2 \mathrm{v})^{-1} \mathrm{~m}^{*}+v(v-1)(1+2 v)^{-1} \mathrm{~m}-\mathrm{z}_{\mathrm{N}^{*}}\right] \\
& \mathrm{E}\left(\mathrm{c}_{\mathrm{D}^{*}}^{*}\right)=\mathrm{E}\left(\hat{\mathrm{y}}_{\mathrm{D}^{*}}\right)-1 / 2 \mathrm{~V}\left[v(v+2)(1+2 \mathrm{v})^{-1} \mathrm{~m}^{*}+v(v-1)(1+2 v)^{-1} \mathrm{~m}-\mathrm{z}_{\mathrm{D}^{*}}\right] \\
& \mathrm{E}\left(\mathrm{c}_{\mathrm{E}}^{*}\right)=\mathrm{E}\left(\hat{\mathrm{y}}_{\mathrm{E}}\right)-1 / 2 \mathrm{~V}\left[v(v-1)(1+2 v)^{-1} \mathrm{~m}^{*}+v(2+v)(1+2 v)^{-1} \mathrm{~m}-\mathrm{z}_{\mathrm{E}}\right] \\
& \text { where } \hat{y} \text { is the log of the flex value of the flex-price solution. }
\end{aligned}
$$




\section{Endnotes:}

1. Milton Friedman, Harry Johnson and others described the ability of flexible exchange rates to absorb foreign disturbances. Sohmen (1961) provides a discussion of some of these arguments. Mussa (1979) provides a rigorous derivation of the extreme version of these arguments that we have in mind.

2. Canzoneri and Henderson's (1991) book provides a representative example of the literature on first generation models of policy coordination.

3. Goodfriend and King (1997) provide an excellent introduction to the New-Keynesian models, or what they call the New Neoclassical Synthesis. This "synthesis" has engendered a new debate on the role of monetary policy. Major contributions to this debate include (but are hardly limited to): Ireland (1996), Rotemberg and Woodford (1997, 1999), King and Wolman (1999) and Erceg, Henderson and Levin (2000). The papers cited in the main text extend the debate to the question of international policy coordination. Other contributions to this emerging literature include: Benigno and Benigno (2000, 2001), Benigno (2000), and Clarida, Gertler and Gali (2001).

4. Actually, $O \& R a$ postulated a constant elasticity function for the utility of money. $O \& R b$, $\mathrm{C} \& \mathrm{~Pa}$ and $\mathrm{C} \& \mathrm{~Pb}$ used the $\log$ specification, as have many others in the literature. We will show how relaxing the log specification to a constant elasticity specification affects the analysis.

5. This too is a result of the rudimentary theory of exchange rate determination in the Workhorse Model.

6. See for example Canzoneri, Cumby and Diba (1999).

7. A log specification of the utility of consumption (combined with a Cobb-Douglas consumption aggregator) implies that the current account is balanced each period; this strategic simplification is due to $\mathrm{C} \& \mathrm{~Pa}$. It greatly simplifies the analysis, since there are no wealth transfers between countries.

8. A detailed discussion of what follows can be found in Canzoneri, Cumby and Diba (2001); see especially the appendix on "unbundling the bundlers", which goes behind the artifice of bundlers.

9. A word on notation may be helpful at this point. An “*” in a subscript denotes a good produced in the foreign country. An "*" superscript on a price signifies that the price is in terms of the foreign currency.

10. CCP is often referred to as "pricing to market"; PCP is often described as "full exchange rate pass through", since the price charged to foreign customers is fully indexed to movements in the exchange rate. $\mathrm{C} \& \mathrm{~Pb}$ consider partial indexation policies. 
11. Three modeling choices allowed household variables to be equal to aggregate variables: (1) households in each country are distributed on the unit interval, (2) each household produces all three goods, and (3) the three goods are weighted equally in the composite consumption good.

12. Actually, (7), (8) and (12) imply (14). As noted earlier, our assumption of "no capital mobility"was not necessary for current account balance; it was an algebra saving contrivance.

13. For $\mathrm{j}=\mathrm{N}$ and $\mathrm{D}$, it is straight forward to derive (17) from (9) and (11). For $\mathrm{j}=\mathrm{E}$, one must also use trade balance, (14), and constant expenditure shares, (7).

14. In an intertemporal version of the model, the interest rate would appear in (10), but with $v=$ 1 , the exchange rate would depend only on current and expected future money supplies. This would not change our basic results.

15. There are, of course, exceptions. For example, Benigno and Benigno (2000) show how to design production subsidies that make the monopolistic competition's temptation to inflate balance the terms of trade's temptation to deflate, letting (in their model) the Nash solution under discretion achieve the flex-price solution; there would still be a gain from coordination, since output is still inefficiently low in the Nash solution. We do not pursue such issues here.

16. Log utility of consumption is a defining characteristic of the Workhorse Model, since it is one of the assumptions necessary to keep the current account balanced in an intertemporal version of the model with non-traded goods.

17. The result does not depend on the linear disutility of work; we would get the same result using a constant elasticity specification for each laborer's work: $(1+\chi)^{-1}\left(Y_{j}(h) / Z_{j}\right)^{1+\chi}$. We should note, however, that even if we generalized both the disutility of labor and the utility of consumption to constant elasticity specifications, we would still have the strong implication that the expected disutility of work is proportional to the expected utility of consumption; see Canzoneri, Cumby and Diba (2001). The goal of monetary policy can be described as maximizing the expected utility of consumption for the whole class of constant elasticity utility functions; there is, in this sense, no tradeoff between consumption and labor supply considerations.

\section{See Henderson and Kim (1999) and O\&Ra.}

19. $\mathrm{C} \& \mathrm{~Pb}$ have shown that it is not necessary to close the model in this way. They go on to define Nash equilibria without deriving explicit closed form solutions.

20. The first best would also eliminate the monopolistic competition distortions. As Henderson and Kim have shown, this might be done with production subsidies.

21. $\mathrm{C} \& \mathrm{~Pb}$ go on to show that there would be a role for policy coordination if households partially indexed the price of their export good to movements exchange rate; for them, PCP (full indexation) and CCP (zero indexation) are two polar cases in which there are no gains from 
coordination.

22. It is easy to see how this happens: According to (17) flex , flex-price output levels should move in proportion to their country's productivity shock, and according to Proposition 2, this will happen in the fixed-price solution if money supplies move in proportion with their country's productivity shock.

23. Section 3 of Canzoneri, Cumby and Diba (2001) provides a detailed discussion of this example in a closed economy model.

24. Erceg, Henderson and Levin (2000) show that the tradeoff they introduce can be expressed as an inflation - output gap tradeoff. We are looking for a separate cost of inflation.

25. $\mathrm{C} \& \mathrm{~Pb}$ did not speculate as to the size of the gains from coordination in their extension of the Workhorse Model. 